\title{
A növekedési hormon és az inzulinszerü növekedési faktorok élettani szerepe
}

\author{
Halmos Tamás dr. ${ }^{1}$ - Suba Ilona dr. ${ }^{2}$ \\ ${ }^{1}$ MAZSIHISZ Szeretetkórház, Metabolikus Ambulancia, Budapest \\ ${ }^{2}$ Bajcsy-Zsilinszky Kórház-Rendelőintézet, Tüdőgondozó Intézet, Budapest
}

\begin{abstract}
Az inzulinszerú növekedési faktorok (IGF-ek) létezését a porcba történő szulfátbeépítés stimulálása kapcsán ismerték fel. Az IGF-ek a növekedési hormonnal (GH) kölcsönhatásban részt vesznek az embrionális fejlődésben és a születés utáni növekedésben. Az IGFl-ek fiziológiai hatása a szövetek növekedése és fejlődése, lipid- és szénhidrát-metabolizmus, túlélés/'anti-aging', gyulladáscsökkentő, anabolikus antioxidáns, neuro- és hepatoprotektív tulajdonságok. A GH-IGF-tengelyról szóló ismereteink szerteágazóak, részben ellentmondásosak, kutatásuk napjainkban is intenzíven folyik. Ezért tartottuk érdemesnek e hatalmas ismeretanyag áttekintését és interpretálását. A GH-IGF-szisztéma múködésével kapcsolatos közlemények tanulmányozása, különös tekintettel a kevésbé ismert anyagcsere-szabályozásra. A növekedési faktorok 75\%-ban a májban keletkeznek GH- és inzulinstimulációra, hatásaikat specifikus receptoraikon fejtik ki, és kötőfehérjék módosítják. Az IGFl növeli az izomtömeget és a csontsűrúséget. A mikrobióta indukálja az IGFl-et, ami elősegíti a csontnövekedést és -átépülést. A rövid láncú zsírsavak, melyek a mikrobióták által fermentált rostokban keletkeznek, IGFl-et indukálnak, ami arra utal, hogy a mikrobióta a csont egészségét is befolyásolja. Az IGFl-nek direkt és indirekt glükózszintcsökkentő hatása is van, fokozza az izomban a szabadzsírsavoxidációt; ez csökkenti a szabadzsírsav-beáramlást a májba, így az inzulin-jelátvitel javul, csökken a máj glükózkibocsátása. Az inzulinszerű peptidek bioaktivitását az agyban a neuronalis túlélés, az izgalmi és gátló neurotranszmisszió, a normális szabadzsírsav-szint fenntartása, a kognitív funkció javítása, a sejtkárosodás elleni védelem, neurogenezis, angiogenezis jellemzik. Az IGFl közvetlenül befolyásolja a cirkadián BMALl-gén expresszióját a hypothalamicus sejtekben. Ez a szabályozás az IGF1 újonnan felismert 'zeitgeber' szerepére utal. Az IGF2 hatásai kevésbé tisztázottak, bár releváns szerepe van a fetus fejlődésében, és protektíven hat az agyra. Az IGF-ek hiánya vagy éppen túlzott jelenléte számos betegségben kimutatható, illetve ezekkel oki összefüggésbe hozható. E felismerés hasznosítása a klinikai orvostudomány legközelebbi feladatai közé tartozik.
\end{abstract}

Orv Hetil. 2019; 160(45): 1774-1783.

Kulcsszavak: inzulinszerü növekedési faktorok, metabolizmus, cirkadián CLOCK, mikrobióta

\section{The physiological role of growth hormone and insulin-like growth factors}

The existence of insulin-like growth factors (IGFs) was recognized in connection with the stimulation of sulfate incorporation into cartilage. IGFs take part in the embryonal development and postnatal growth, in interaction with the growth hormone (GH). The physiological effects of IGFl are promotion of tissue growth and development, stimulation of cell proliferation, effects on lipid and carbohydrate metabolism, anti-aging, anti-inflammatory, anabolic, anti-oxidant, neuro- and hepatoprotective properties. Our knowledge about the GH/IGF axis is diverse, partly contradictory, their research is continued intensively nowadays. We considered it worthwhile to review and interpret this information. Study on GH/IGF medical reports, with particular reference to the less known metabolic control. $75 \%$ of the growth factors are produced in the liver by $\mathrm{GH}$ and insulin stimulation; their effects are expressed on specific receptors, and modified by specific binding proteins. IGFl directly increases the muscle mass, bone density, and the structure of the bones. Intestinal microbiota induces secretion of IGFl, which promotes the development and remodeling of the bones. Short-chain fatty acids, produced in microbial fermented fibers, induce secretion of IGF1, suggesting that microbial activity also affects bone health via IGFl. IGFI also has a direct and indirect glucose-lowering effect, enhances free fatty acid oxidation in the muscle, reducing the flow of free fatty acid into the liver, improving insulin signaling, resulting in the reduction of hepatic glucose output, and improves insulin sensitivity. IGFl directly influences the expression of circadian BMALl in hypothalamic cells: this refers to the newly recognized 'zeitgeber' role of IGFl. The bioactivity of insulin-like peptides in the brain is characterized by neuronal survival, excitatory and inhibitory neurotransmission, maintenance of normal free fatty acid levels, improvement of cognitive function, protection against cell damage, neurogenesis and angiogenesis. The effects of IGF2 are less outlined, however, it has a relevant role in the development of the fetus, and acts protectively on the brain. Lack or 
over-expression of IGFl can be detected or may causally associated in many pathological conditions. According to these collected data, insulin sensitivity may be improved by different pathways. The role of IGFs in these processes should be a task of future research.

Keywords: insulin-like growth factors, metabolism, circadian CLOCK, microbiota

Halmos T, Suba I. [The physiological role of growth hormone and insulin-like growth factors]. Orv Hetil. 2019; 160(45): 1774-1783.

(Beérkezett: 2019. április 16.; elfogadva: 2019. május 24.)

\begin{abstract}
Rövidítések
$\mathrm{AKT}=$ szerin/treonin specifikus proteinkináz-B; ALS = (acidlabile subunit) savérzékeny alegység; Cry = (cryptochrom) kriptokróm gének; CSF = cerebrospinalis folyadék; FFA = (free fatty acid) szabad zsírsav; $\mathrm{GH}=$ (growth hormone) növekedési hormon; GHR $=$ GH-receptor; IGFl $=$ (insulin-like growth factor 1) inzulinszerú növekedési faktor-1; IGFlR = IGFl-receptor; IGF2 = (insulin-like growth factor 2$)$ inzulinszerü növekedési faktor-2; IGF2R = IGF2-receptor; IGFBP = $(\mathrm{IGF}$ bounding protein) IGF-kötő fehérje; IGFR = IGF-receptor; ILI $\beta$ = interleukin-1-béta; IR = inzulinreceptor; IRA-IGF1R és IRB-IGFIR = hibrid receptorok; IRS = (insulin receptor substrate) inzulinreceptor-szubsztrát; LRPI $=($ low-density lipoprotein receptor-related protein 1 ) alacsony súrúségú lipoproteinnel kapcsolatos fehérje-1; mRNS $=$ (messenger) hírvivő ribonukleinsav; $\mathrm{mTOR}=($ mammalian target of rapamycin $)$ a rapamicin célpontja emlősökben; Per $=$ period gén; $\operatorname{PPAR} \gamma=$ (peroxisome proliferator-activated receptor $\gamma$ ); peroxiszómaproliferátor aktiválta receptor-gamma; $\mathrm{PI} 3 \mathrm{~K}=($ phosphatidylinositol-3-kinase) foszfatidilinozitol-3-kináz; PTH = (parathyroid hormone) mellékpajzsmirigy-hormon; $\mathrm{PTHrP}=$ (parathyroid hormone-relatede peptide receptor) mellékpajzsmirigy-hormonnal kapcsolatos peptidreceptor; RXR $\alpha=$ (retinoid X receptor alpha) 9-cisz-retinsav-receptor-alfa; SAT= (subcutaneous adipose tissue) szubkután zsírszövet; SCFA = (short chain fatty acid) rövid láncú zsírsav; SIRTl = (silent information regulator 1) szirtuinfehérje-család (csendes információszabályozó-1 $)$; STAT5 = (signal transducer and activator of transcription 5 ) jelátviteli és transzkripciós aktivátor-5; T2DM = 2 -es típusú diabetes mellitus; $\mathrm{TH}=$ (thyroid hormone $)$ pajzsmirigyhormon; TNF $\alpha=$ tumornekrózisfaktor-alfa; VAT $=($ visceral adipose tissue) zsigeri zsírszövet
\end{abstract}

Az inzulinszerú növekedési faktor-1 és -2 (IGF1, IGF2) jelentős szerkezeti homológiát mutat az inzulinnal. A szerkezeti hasonlóság arra utal, hogy a proinzulin, az IGF1 és az IGF2 egyetlen prekurzor molekulából alakult ki sok millió évvel ezelőtt. Ez a prekurzor molekula jelezte a primitív organizmusok sejtjeinek, hogy megfelelö-e a tápanyagellátás a metabolikus szükségletekhez, a fehérjeszintézishez és a sejtproliferációhoz. A gerincesek megjelenésével az inzulin elkülönült az IGF-ektől, kialakult az agyalapi mirigy, mely növekedési hormont termelt. E hormonok funkciója tette lehetővé a tápanya- gok elérhetőségének szabályozását az éhezés és a jóllakottság időszakában, valamint megfelelő szignálokat és szubsztrátot biztosított a növekedéshez [1].

\section{Az IGF-rendszer felfedezésének története}

Az IGF-család elsóként identifikált tagja az inzulin volt, melynek tisztázódott a glükózanyagcserében betöltött szerepe. 1923-ban F. Banting, Ch. Best és JJ. Macleod felfedezte, hogy az inzulin alkalmas a diabetes kezelésére; 1958-ban F. Sanger elsóként határozta meg az inzulin aminosavszekvenciáját [2]. Az IGF-ek létezését elöször Salmon és Daughaday feltételezték 1957-ben. Eredeti tanulmányukban felfedezték, hogy a növekedési hormon (growth hormone $=\mathrm{GH}$ ) nem közvetlenül stimulálja a szulfát beépítését a porcba, hanem valamely szérumfaktoron keresztül $[3,4]$. Ezt a faktort eredetileg szulfatációs faktornak, majd somatomedinnek és végül inzulinszerú növekedési faktor-1-nek (IGFl) és inzulinszerü növekedési faktor-2-nek (IGF2) nevezték. Az ,inzulinszerü" terminológiát azért alkalmazták, mert ezek a faktorok képesek stimulálni a zsírsejtek és az izom glükózfelvételét, s mind az IGFl, mind az IGF2 50\%-os homológiát mutat az inzulinnal, és bizonyos mértékú átfedést a jelátviteli utakban [5]. Az IGF-ek hatékony mitogenetikus tulajdonsággal bíró peptidek. Inzulinszerú proteineket nemcsak valamennyi gerinces élőlényben, hanem puhatestúekben, férgekben, rovarokban is kimutattak. Ezek a megfigyelések arra utaltak, hogy azok a gének, melyek mind a gerinces, mind a puhatestúek inzulinszerúen ható molekuláit kódolták, egy közös ősi géntől származnak, erősítve az inzulin-,,szupercsalád” koncepciót [6]. Az IGF-ek részt vesznek az embrionális fejlődésben és a születés utáni növekedésben. Az IGFlnek sokféle fiziológiai hatása van, mint a szövetek növekedése és fejlődése, proliferatív hatás, lipid- és szénhidrát-metabolizmus, élettartam-szabályozó, gyulladáscsökkentő, anabolikus, antioxidáns, neuro- és hepatoprotektív tulajdonságok. Az IGFl megvédi a mitokondriumokat a megnövekedett metabolizmus által okozott oxidatív károsodásoktól, növeli az ATP szintézisét, és csökkenti a szabad gyökök intramitokondriális termelődését [7] (1. ábra). 


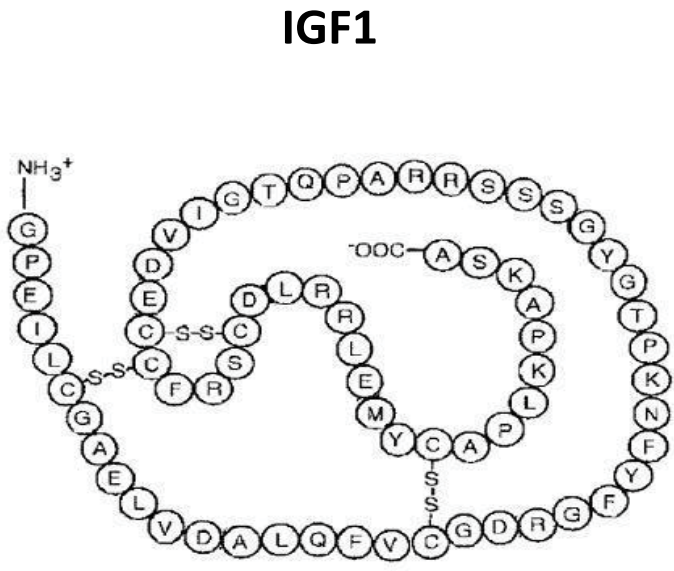

1. ábra

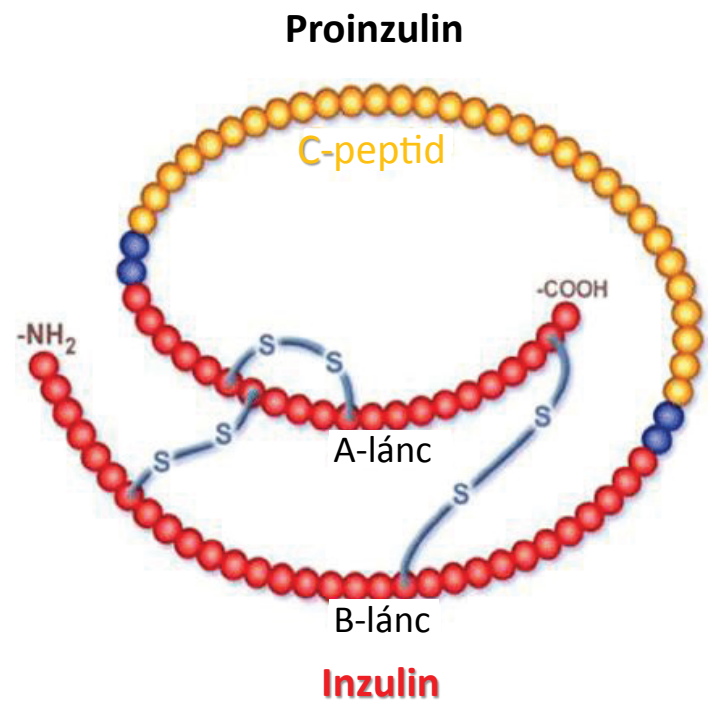

Az IGF-rendszer a szervezetben mindenütt jelen van, parakrin, endokrin és metabolikus hatásai vannak. Az inzulin, az IGF1 és az IGF2 a szignifikáns szerkezeti homológia ellenére jelentős különbségeket mutatnak a receptoraikhoz viszonyított affinitást illetően [1].

\section{Az IGF-ek és receptoraik}

Az IGF-ek jelátvivő fehérjemolekulák ( 7,5kDa), melyek hatásait az IGF-receptor (IGFR) közvetíti, és a receptorhoz történő hozzáférést az IGF-kötő fehérjék (IGF bounding protein = IGFBP) szabályozzák; ezek nagysága változó ( 22-31 kDa között), aminosavszekvenciájuk és szerkezetük hasonló [8]. A közös eredet talaján a proinzulinhoz szerkezetileg hasonló IGF-ek interakcióba léphetnek az inzulinreceptor-A- és -B-izoformokkal, az l-es típusú IGF-receptorral (IGFlR) és a hibrid receptorokkal (IRA-IGFlR és IRB-IGF1R), így mediálják a jelátvitelt a különböző szövetekbe, ezáltal szabályozzák a fehérje-, szénhidrát- és zsírmetabolizmust $[9,10]$. A hepatocyták és az érett adipocyták bőségesen tartalmaznak IRB-t. Az inzulinnak az IGFl-nél 2 nagyságrenddel nagyobb az affinitása az IRB-hez, így e szövetekben az inzulin szerepe meghatározó az anyagcserében. A praeadipocyták bőséges IGFlR-rel rendelkeznek, melyekhez az IGFl affinitása két nagyságrenddel nagyobb, mint az inzuliné; itt az IGFl közvetíti a praeadipocytaproliferációt, -differenciálódást és -túlélést [11]. Az adipocytadifferenciálódás során az IGF1R expressziója eltolódik az IRB expressziójának irányába. Az izomban mind az inzulinreceptorok, mind az IGF1R-ek jelen vannak, ezek és a hibrid receptorok is hozzájárulnak a metabolikus jelátvitelhez. Felismerték, hogy az IRA-hoz az inzulinnal hasonló affinitással kötődő IGF2nek is lehet bizonyos metabolikus szerepe [12]. Az IGF/ mannóz-6-foszfát-receptor (IGF2R) megköti az IGF2-t, ezáltal szabályozza elérhetőségét a jelátvitel számára [13]. Mindezek a receptorok tirozin-kináz-aktivitással bírnak, így természetes és hatékony aktiválói az AKTszignálútnak $(\mathrm{AKT}=$ szerin/treonin specifikus proteinkináz-B), mely a sejtnövekedés és -proliferáció stimulálásért, valamint a programozott sejthalál gátlásáért felelős. Az IGFl az AKT-nak egyik legfontosabb természetes aktiválója.

\section{IGF-kötő proteinek}

Az IGF-ek egyedülálló tulajdonsága, hogy képesek kötődni az inzulinszerü növekedési faktort kötő fehérjékhez (IGFBP-k) [14]. Eddig 6 nagy affinitású IGFBP-t írtak le, melyek közül a IGFBP3 a legfontosabb: koncentrációja emelkedik a GH hatására, és ez a teljes IGFIszint növekedésének szignifikáns hányadát teszi ki [15]. Az IGFl elérhetőségét szabályozzák az IGF-kötő fehérjék, melyek az IGFl felezési idejét percekről órákra növelhetik (a leggyakrabban tercier komplexet képezve a savérzékeny alegységgel [ALS = acid-labile subunit] és az IGFBP3-mal), ugyanakkor blokkolják az IGF1R-hez való kötődését [16].

Az IGFBP-k képesek az IGFl-et bizonyos szövetekbe irányítani, gátolni vagy fokozni az IGFl hatásait, mely független szubsztrátként hathat az IGFlR-re és más specifikus membrán-, intracelluláris vagy nukleáris receptorokra $[7,17]$. Az IGFBPl-et az anyagcsere-betegségek résztvevői közé sorolták, mivel mennyiségét az inzulin, a glükóz és a GH negatívan szabályozza [18]. Praediabetesben az IGFBPl csökken, de a betegség előrehaladásával hasnyálmirigy-szekréciós kapacitása is csökken, ami krónikus inzulinhiányt okoz, valamint fokozza az IGFBPl-szintet [19]. Az IGFBP-k fontos biológiai fo- 
lyamatokat modulálnak, mint sejtproliferációt, -túlélést, -migrációt, -öregedést, autofágiát és angiogenezist. E kötőfehérjék szabályozzák, módosítják a növekedési faktorok kiterjedt funkcióit, szerepük elválaszthatatlan az IGF-ek valamennyi metabolikus és immunológiai múködésétől [16].

\section{Az inzulinszerü növekedési faktor-1 (IGF1)}

Az IGF1 70 aminosavból álló polipeptid hormon - endokrin, parakrin és autokrin hatásokkal -, amely szerkezeti homológiát (>60\%) mutat az IGF2-vel és a proinzulinnnal. Főleg a májban termelődik (a keringő IGFl 75\%-a) a GH és inzulinstimuláció hatására. Ugyanakkor az IGFl közvetíti a GH anabolikus és növekedést elősegítő hatásait, és mitogenetikus, valamint inzulinszerü metabolikus aktivitással is rendelkezik [20]. Egészséges egyénekben más szövetek is termelnek IGFl-et a GH parakrin/autokrin hatására [21]. Az IGFl expreszszióját más hormonok is befolyásolják, így ösztrogének, adrenokortikotrop hormon, tireotropinfelszabadító hormon, luteinizáló hormon, folliculusstimuláló hormon, humán koriongonadotropin, inzulin és más növekedési faktorok, mint vérlemezke-eredetű növekedési faktor, epidermális növekedési faktor és fibroblastnövekedési faktorok, csakúgy, mint az életkor, a nem és a táplálék összetétele. E faktorok a tápanyagbevitel változásaival koordináltan befolyásolják az IGFl hatását a növekedés és az anyagcsere szabályozására [22].

\section{IGF1-szintézis}

Az IGFl-szintézist a táplálkozás és a növekedési hormon stimulálja a májban és más szövetekben. Nemi különbségek vannak a májban a GH-érzékenység szempontjából: a nőknek több GH-ra van szükségük hasonló hatáshoz [23]. Kalóriarestrikció esetén emlősökben kevesebb IGFl szintetizálódik, a máj refrakterré válik a GH-stimulációra [24]. Ez gátolja a növekedést és a fehérjeszintézist, ha a tápanyagok elérhetősége veszélybe kerül. Étkezés után a GH-ra való reakciókészség és az IGFlszintézis helyreáll. Nem kielégítő szénhidrátfogyasztás esetén a portalis vénás inzulinkoncentráció csökkenése az IGFl szintézisének csökkenését okozza a májban $[25,26]$.

A GH a receptora (GHR) extracelluláris doménjéhez kapcsolódik, amely jelen van a különböző sejtek felszínén. Ez a kötődés az intracelluláris protein JAK2 (Januskináz) autofoszforilációját indukálja, ami az aktivált GHR-rel együtt indukálja a STAT5 (signal transducer and activator of transcription 5 ) foszforilációját. Ezt követi a STAT5 dimerek transzlokációja a nucleusba, ahol determinálják számos célgénnek, így az IGFl-nek és az ALS-nek, a leucinban gazdag glikoproteinnek a szabályozását [27]. A JAK protein-tirozin kinázokat mint a citokinreceptor-alegységek integráns részeit azonosították. Szerepük van az embrionális fejlődés kiinduló lépésében, a szöveti enzimaktivációban, a haemopoeticus rendszer fejlődésében és differenciálódásában, a veleszületett és adaptív immunitásban és a gyulladásos reakciókban.

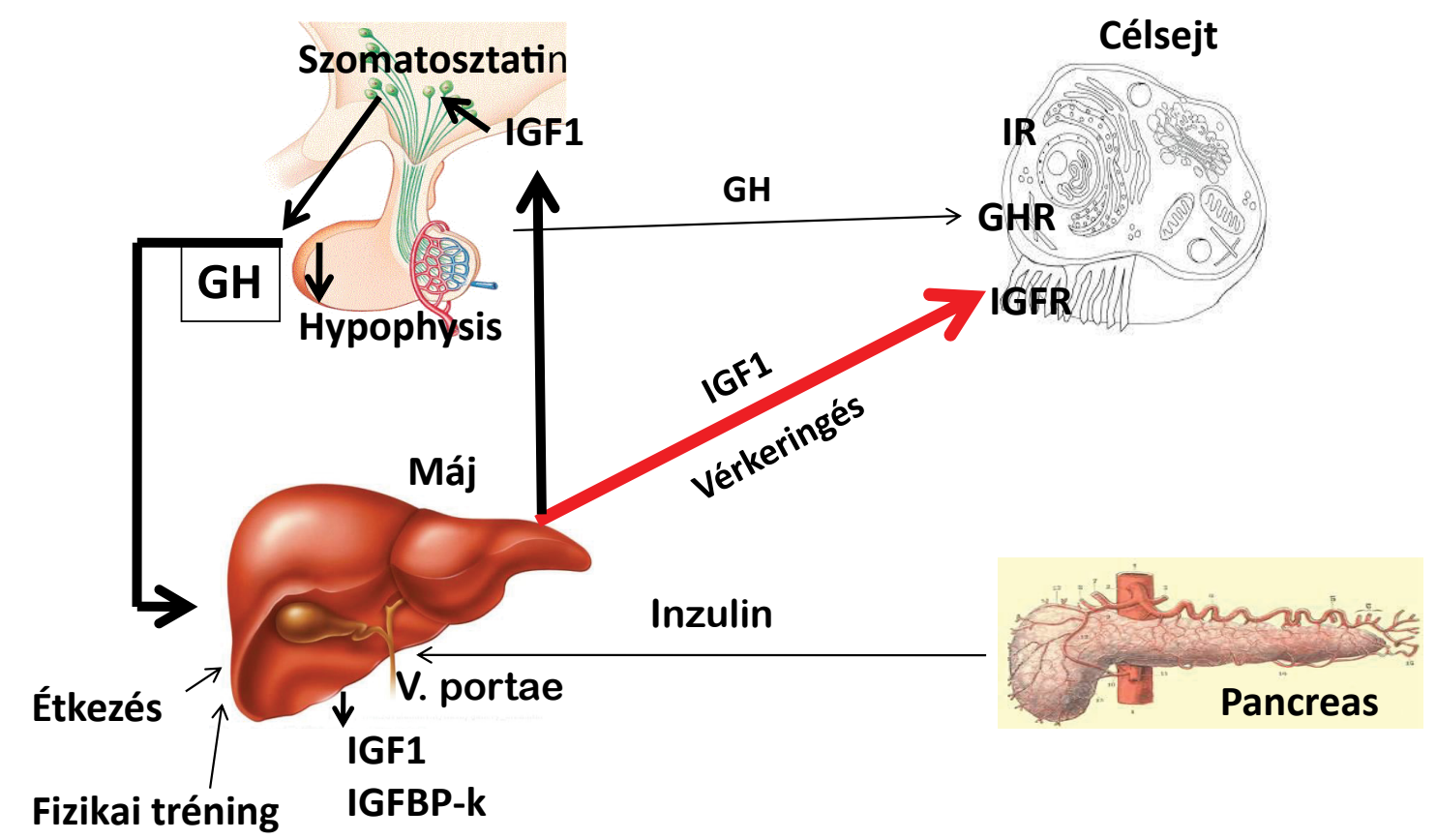

\begin{tabular}{l|l} 
2. ábra & $\begin{array}{l}\text { Az IGFl-szintézis. Az IGFl főként a májban termelődik GH és inzulin hatására. Az IGFl negatív visszacsatolás útján gátolja a GH szekrécióját } \\
\text { GH = növekedési hormon; GHR = GH-receptor; IGFl = inzulinszerú növekedési faktor- } 1 ; \text { IGFBP = IGF-kötő fehérje; IGFR = IGF-receptor; IR = } \\
\text { inzulinreceptor }\end{array}$
\end{tabular} 
Az IGFl negativ „feedback” mechanizmussal gátolja a GH-szekréciót azáltal, hogy stimulálja a szomatosztatin termelését az agyalapi mirigyben. A GH is fontos metabolikus szerepet tölt be, amely független az IGFl hatásaitól, beleértve a lipolízis stimulálását és az inzulin-jelátvitel gátlását a zsír- és az izomszövetben. Így a GH-nak a gátlása IGFl-visszacsatolás által, a közvetlen metabolikus hatások csökkentésével növeli az inzulinérzékenységet. Az inzulin mellett és annak hatását kiegészítve az IGFl közvetlenül is szabályozza a fehérje-, a szénhidrátés a zsíranyagcserét. Az IGFl növeli az inzulinérzékenységet, függetlenül a GH hatásától is [28] (2. ábra).

\section{A fizikai tréning hatásai az IGFl-re}

Az izommúködés ismert hatása a plazma IGFl-szintjének növekedése. Egyszeri mérsékelt vagy intenzív fizikai munka a teljes IGFl-plazmaszintet 10-30\%-kal növeli, a „csúcs” 5-10 perccel a tréning kezdete után áll be [29]. Ez a rapid hatás az IGFl-nek a szöveti raktárakból történő kiáramlása vagy az IGFBP3 proteolitikus bontása miatt következik be. Az intenzív izommunka a pHértéket drámaian csökkenti, ez negatívan hathat az IGF$\mathrm{BP}$ affinitására az $\mathrm{IGFl} / 2$ iránt [30]. Fizikai tréning során a hippocampalis neuroprogenitor sejtek megszaporodnak, javul a neuroglia múködése [31]. Újabban bebizonyították, hogy az IGFl centrális adagolása szintén javította a teljes test inzulinszenzitivitását. Ez azt is jelentheti, hogy a gyors IGFl-növekedés a plazmában nemcsak periférikus hatás, hanem centrális effektus eredménye is lehet [32].

\section{A GH/IGFI hatása a csontokra és az izomra}

A vázizomzat és a csontrendszer fejlődésének, növekedésének és fiziológiai szilárdságának fenntartása érdekében számos növekedési tényezőre van szükség. Ezek közül az egyik fő szereplő az IGFl, mely közvetlenül növeli az izomtömeget és a csontsűrüséget. A két szervrendszer közötti mechanikus kölcsönhatás közvetetten is megváltoztatja az izom-csont rendszer állapotát, túlmutatva a receptoron keresztül ható közvetlen aktivitáson.

A csontrendszer fejlődése rendkívül összehangolt folyamat, amelyhez először a releváns prekurzorok összegyưlése és jövőbeli csonthelyekre irányuló migrációja, valamint chondrogen és osteogen vonalakra való szétválása szükséges, és a végső differenciálódás során nyerik el porc- vagy csontképző képességüket. A csontvázképződést, amely meghatározza a csontok számát és alakját, a progenitorok felvétele és „elkötelezettsége” szabályozza; a csontnövekedési ráta elsősorban a chondrogen és osteogen sejtek proliferációjától, túlélésétől és differenciálódásától függ. A növekedési ráta is IGFl-szignált igényel. Úgy látszik, hogy az IGFI közvetlenül hat az izom- ra és a csontokra, és potenciálisan közvetve is hat a csontokra, az izomtömeg növelése útján.

Az IGFl csontképződést stimuláló hatását postnatalisan elsősorban a GH és a parathormon (PTH) szabályozza, bár a pajzsmirigyhormon $(\mathrm{TH})$ is szerepet játszik A glükokortikoidok viszont csökkentik az IGFl expreszszióját a növekedési lemezekben, ami valószínúleg hozzájárul a csontváz növekedésére gyakorolt negatív hatásukhoz. Az nem világos, hogy IGFl-expresszió szabályozása az intrauterin fejlődés során hogyan történik, de lehetséges, hogy a PTHrP-nek (parathyroid hormone-related peptide receptor) van szerepe [33].

\section{Az IGF1 metabolikus hatásai}

Bár az IGFl fontos növekedési tényező, az összes sejttípus növekedését serkenti, jelentős metabolikus hatásai is vannak. Az IGFl jelzi a sejteknek, hogy megfelelő tápanyag áll-e rendelkezésre az apoptózis elkerüléséhez, a sejtfehérje-szintézis fokozásához, a sejthipertrófiához és a sejtosztódás stimulálásához. Az IGFl még felnőtt egyének szöveteiben is, így például a neuronokban és a vázizmokban is fontos trofikus hatásokat fejt ki, melyek a celluláris metabolizmus megváltozásához vezethetnek. Mivel az IGFl-receptorok mindenütt jelen vannak, ezek a változások minden sejttípusban előfordulhatnak. Az IGFlR stimulálása biztosítja a protein-, a szénhidrátvagy a zsíranyagcsere különböző sejttípusok közötti koordinációját. E folyamatok az inzulinnal összhangban vannak, és különböző célszövetekben vagy az inzulin, vagy az IGFl lehet a metabolikus folyamatok elsődleges meghatározója [10].

\section{Az IGFl és a szénhidrát-metabolizmus}

Az IGFl bizonyos perifériás szövetekben elősegíti a glükózfelvételt, hatása az inzulinénak 4-7\%-a. Exogén IGFl beadása csökkenti a szérumglükózszintet nemcsak egészséges egyénekben, hanem 2-es típusú diabeteses (T2DM) betegekben is [34]. Kísérletesen igazolták, hogy inzulinrezisztencia esetén az inzulin/IGFl hibrid receptor expressziója fokozódik az izomban és a zsírszövetben [35]. Az IGFl szérumkoncentrációja 100-szor nagyobb az inzulinéhoz képest, ha azonban IGFBP-hez kötődik, biológiai aktivitása módosul, és a szabad kötetlen formától eltérő hatásokat mutat. Nagy dózisú IGFl beadása hypoglykaemiát okoz, annak ellenére, hogy a keringő inzulin koncentrációját hatásosan szupprimálja [36]. Ezt a hatást az inzulinreceptor közvetíti, de kísérleti, inzulinreceptorgén-KO-egerekben is észlelték az IGFl hatékony, glükózszintet csökkentő hatását, vagyis a hypoglykaemiás hatást részben a saját IGFlR közvetíti [37].

Az IGFl-nek indirekt glükózszintcsökkentő hatása is van azáltal, hogy fokozza az izomban a FFA-oxidációt, ez csökkenti a FFA-beáramlást a májba, így az inzulinjelátvitel javul, és ennek következtében csökken a máj glükózkibocsátása [38]. Az IGFl csökkenti a szérum- 
GH-szinteket, ezáltal gátolja a májban a GH hatásait, így fokozza az inzulin hatását [39]. A GH mind a zsírszövetben, mind a májban stimulálja a PI3K (foszfatidilinozitol-3-kináz) p85-alegységének szintézisét, ami a pl10alegység aktivitásának gátlásához és így az inzulin hatásának antagonizálásához vezet $[40]$. Az IGFl tehát közvetve modulálhatja a szénhidrát-anyagcserét a GHszuppresszió és az inzulinhatás fokozása révén.

Az IGFBP-k is szerepet játszanak a glükózanyagcserében. Az IGFBPl a glükózszinteket a szabad IGFl-re gyakorolt hatásával szabályozza. Az IGFBP2 hatásai inzulinhoz kötöttek, bár csak hyperinsulinaemia esetén [41]. Az IGFBP3 egy nukleáris receptorhoz, a 9-ciszretinsav-receptor-alfához $(\mathrm{RXR} \alpha)$ kötődik, mely interakcióba lép a peroxiszómaproliferátor aktiválta receptorgammával (PPAR $\gamma$ ), egy olyan nukleáris proteinnel, mely részt vesz a glükóz- és a lipidanyagcsere szabályozásában $[42,43]$.

\section{Az IGFl és a lipidmetabolizmus}

Az IGFl elősegíti a praeadipocytadifferenciálódást, azonban a praeadipocyták a differenciálódásuk során beszüntetik az IGFlR-ek expresszálását, és ezt a funkciót az inzulinreceptorok veszik át, amelyek száma jelentősen megnövekszik. Így a zsírszövetben az élettani IGFlkoncentrációk nem hatékonyak a lipidszintézis vagy lipo- lízis változásainak stimulálásában $[44,45]$. Az érett adipocyták nem célsejtjei az IGFl-nek, de termelik azt. Szövettenyészetben az adipocyták több IGF2-t termelnek, mint IGFl-et és elsősorban IGFBP4-et. Az IGFl szekrécióját a GH, az interleukin-1- $\beta$ (IL1 $\beta$ ) és a TNF $\alpha$ szabályozza, míg az IGF2-t kizárólag a TNF $\alpha$ regulálja, így ezek a citokinek kontrollálhatják az adipocyták homeostasisát, szabályozva a lokális IGFl-szintézist [46].

$\mathrm{Az}$ inzulin hatásos serkentője a lipidszintézisnek, az inzulin- és IGFl-receptorok tirozinfoszforilációja aktiválja az inzulinreceptor-szubsztrátot (IRS), ennek következtében indul be a jelátviteli kaszkád, és gátlódik a trigliceridek lebontása. A GH antagonizálja az inzulin hatásait [47]. A megnövekedett FFA-efflux a zsírszövetből a zsírérzékeny szövetekbe (májba, vázizomzatba és szívizomba) irányul, megnövelve az IRS szerinfoszforilációját; ez a tirozinresiduumok foszforilációjának gátlásához vezet az IRS-ben, ami inzulinrezisztenciát okoz. Az IGFl elősegíti a zsírsavtranszportot az izomban, és ennek gátlása súlyos következményekhez vezet, mint inzulinrezisztencia és esetenként diabetes [48]. Ennek oka, hogy a máj a keringő FFA-t teljes mértékben felveszi, amely azután interferál az inzulinnal és az IGF-jelátvitellel, és esetenként steatosis hepatis (nem alkoholos zsírmáj) kialakulásához vezethet. Az IGFl két fó hatása tehát: 1) FFA-hasznosítás az izomzat által és 2) a $\mathrm{GH}$ gátlása (3. ábra).

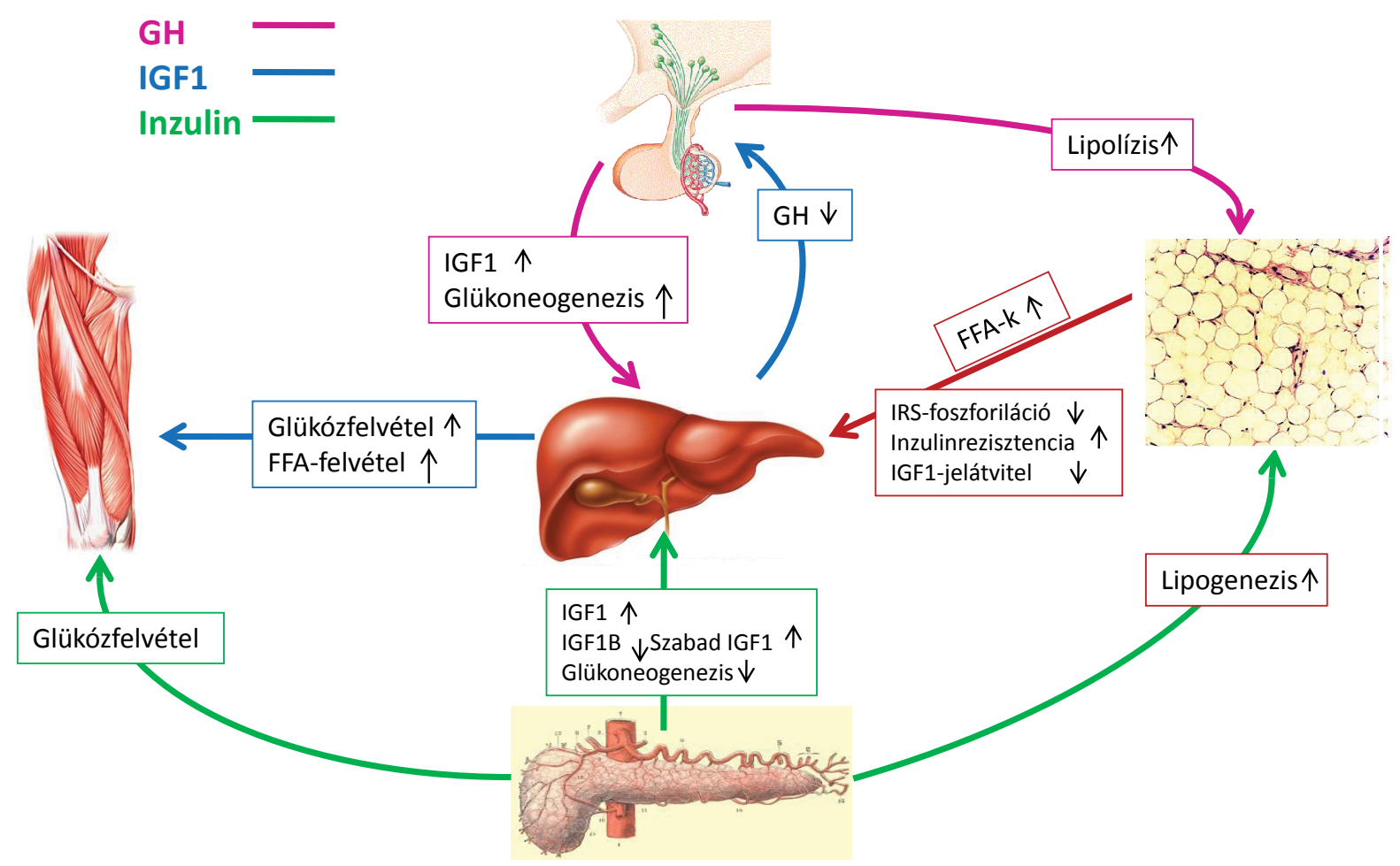

3. ábra $\quad$ A GH-IGFl-tengely és az inzulin szerepe a szénhidrát- és zsíranyagcserében. Az inzulin mellett és annak hatását kiegészítve az IGF1 közvetlenül is szabályozza a szénhidrát- és a zsíranyagcserét

FFA = szabad zírsav; GH = növekedési hormon; IGFl = inzulinszerű növekedési faktor-1; IRS = inzulinreceptor-szubsztrát 


\section{A GH-IGF-szisztéma és a visceralis zsírszövet}

A növekedési hormon fontos közvetlen hatással van az érett adipocytákra többféle jelátviteli útvonalon keresztül, ami fokozott lipolízist és csökkent lipogenezist eredményez [49]. A növekedési hormon közvetett hatással is van az adipocyta növekedésére és differenciálódására az IGFl-szintézis stimulálásával. Az IGFl serkenti a praeadipocyták proliferációját, és az inzulinnal összhangban stimulálja az adipocyta differenciálódását. A praeadipocytától az adipocytáig történő differenciálás során az l-es típusú IGF-receptorok expressziója csökken, és az IGFl-nek az inzulinhoz képest kevésbé fontos közvetlen szerepe van az érett adipocytákban [10]. Az IGFl és az inzulin okozta receptoraktiváció több intracelluláris kinázt serkent, köztük a szerin/treonin kináz AKT-ot.

A fehér zsírszövetben a rapamicin-útvonal aktivációja központi szerepet játszik az IGFl-re és az inzulinra adott proliferatív válaszban [50]. Ezen útvonal aktiválása elősegíti a gyulladásos citokinek hiperszekrécióját. Az mTOR (mammalian target of rapamycin) egy kináz, amelyet emberben az mTOR-gén kódol. Az mTOR tirozin-protein kinázként múködik, mely elősegíti az inzulinreceptorok és az IGFlR-ek aktivációját.

Elhízott egyénekben az AKT-útvonal IGFl-aktiválása károsodott a VAT-ból (visceral adipose tissue) származó praeadipocytákban a SAT-hoz (subcutaneous adipose tissue) viszonyítva, és ez részben magyarázatot adhat e szövetekben a proliferatív válaszok különbözőségére [51]. Az IGFl és az inzulin által közvetített útvonalak aktiválják a FoxOl-et, egy transzkripciós faktort is, amely számos, a zsírszövet differenciálódását szabályozó gént koordinál [52]. A GH-IGF-rendszer szerepet játszhat a glükokortikoidérzékenység módosításában is a zsírszövetben [53].

\section{A fehérje-anyagcsere és az IGFI}

A vázizomzatban az IGFl serkenti az aminosavtranszportot, de egyúttal közvetlen stimulánsa a fehérjeszintézisnek is, és fontos gátlója a proteinlebontásnak. A fehérjeszintézis jelentős fokozódását olyan koordinált molekulárbiológiai hatások eredményezik, melyek ismertetése meghaladná e dolgozat kereteit [10].

\section{Inzulinszerü növekedési faktor-2 (IGF2)}

Az IGF2 hatásai kevésbé tisztázottak, bár releváns szerepe van a fetus fejlődésében, és protektíven hat az agyra $[54,55]$. Az IGF2 képes a saját receptorán (IGF2R) keresztül hatni, amely meghatározatlan hatású mannóz6-foszfát transzmembrán fehérje. Úgy gondolják, hogy mint egy 'scavenger' receptor, megköti az IGF2-t és az IGFl-et az extracelluláris térből, megsemmisítés céljából, és intracelluláris célokat is szolgál [56]. Újabb felfedezés, hogy az IGF2R aktiválja a G $\propto$ q-fehérjéket a cardi- omyocytákon. A G-proteinek $\left(\mathrm{G}_{\alpha \mathrm{q}}\right.$ vagy $\left.\mathrm{G}_{\mathrm{q} / \mathrm{ll}}\right)$ aktiválják a foszfolipáz-C-t (PLC), mely részt vesz különböző celluláris jelátviteli utakban [57]. Az IGF2 az IGF1R-en és hibrid receptorokon is képes hatni, de csökkent affinitással.

\section{Inzulinszerü növekedési faktorok az agyban}

Az inzulinszerú peptidek bioaktivitása az agyban: a neuronalis túlélés, izgalmi és gátló neurotranszmisszió, a normális szabadzsírsavszint fenntartása, a kognitív funkció javítása, védelem a sejtkárosodás ellen, neurogenezis, angiogenezis és amyloid clearance [58].

Az IGFl és az IGFlR a különböző agyterületeken szoros közelségben expresszálódnak, ami parakrin vagy autokrin funkcionális hurokra utal. Az IGFl expresszálódik a rágcsálóembrióban, a születés utáni második héten éri el a csúcsát, de továbbra is folytatja expresszióját a felnőttagyban is, különösen az idegsejtekben. Az IGF2 viszont elsősorban a mesenchymalis szövetekben, föként a meninxen és a chorioid plexusban expresszálódik. Az utóbbi struktúra a cerebrospinalis folyadék (CSF) fó IGF2-forrása. Az IGF1R széles körben expresszálódik, regionális eloszlást is mutat, amely a legkifejezettebb a fejlődő kisagyban, a középagyban, a nervus olfactoriusban és a hátsóagy ventralis részében [59]. Az IGF1Rexpresszió szintje a születés után gyorsan csökken a felnőttek szintjéig, de viszonylag magas marad a chorioid plexusban, a meninxen és az érrendszerben [60].

Az IGF-peptidek befolyásolhatják az agymúködést akár helyi szöveti expresszió, akár perifériás keringő peptidek révén, amelyek átjutnak a vér-agy-gáton. Az áteresztett keringő IGF-ek magukban foglalják az IGF1R-t és egy, az alacsony sűrûségú lipoproteinreceptorhoz kapcsolódó fehérjét (low-density lipoprotein receptor-related protein $1=\mathrm{LRPl}$ ), és ezek az IGF-ek elérhetik a cerebrospinalis folyadékot, valamint a hypothalamust és a hippocampust. Az agy más területeit ezután speciális szállítási mechanizmusokon keresztül érik el. Kísérleti bizonyítékok azt sugallják, hogy az IGFl-hez kapcsolódó peptidek, köztük az inzulin, az agy egyes régióiban is termelődnek [61]. Így mind a helyi termelésből, mind a perifériás keringésből származó peptidek szerepet játszhatnak az agymúködés szabályozásában.

A neurotrop hatások mellett a keringő IGFl a kognitív funkcióra is hatással van. A humán megfigyelések szerint, és ez állatmodelleken is igazolódott, a szérum IGFl-szintjének csökkenése kognitív diszfunkcióval jár együtt. Ezek a kognitív zavarok reverzibilisek voltak az IGFl tartós szisztémás adagolására. Ezen eredmények azt sugallják, hogy az IGFl neurotrop hatásai befolyásolják a glutamaterg szinapszisokat a hippocampalis körökön belül, ezáltal befolyásolva a tanulást és a memóriát. Az IGFl egyéb hatásai az agysejtekre is kiterjednek, 
ezek a sejtsérülés elleni védelem, a neurogenezis, az angiogenezis és az amyloid clearance [62, 63].

Az IGF1-hez hasonlóan az IGF2 is szerepet játszik a memória javításában [64]. Bár az IGF2R-nek a legmagasabb az affinitása az IGF2 iránt, nincs intrinszik jelátvivő funkciója, így az IGF2-hatások többnyire az IGF1R és/ vagy az IR közvetítésével érvényesülnek. Az IGF2mRNS és a fehérje expressziója a hippocampalis régiókban fokozódik a rágcsálók elhárítási tréningje után.

A 6 IGFBP közül az IGFBP2, -4 és -5 expressziója az agyban sokkal kifejezettebb, mint a többieké. A perifériás rendszerhez hasonlóan, az IGFBP-k szabályozó szerepet játszanak az IGF-ek megkötésével. Általánosságban elmondható, hogy az IGFBP-k géndeletiója és transzgenikus túltermelése befolyásolta az IGF-ek hatását az agy fejlődésére, de az IGFBP-k független hatását nem igazolták [65].

\section{A bélmikrobióta és az IGFl}

A bélmikrobióta képes dinamikusan szabályozni a keringő IGFl szintjét. Az adatok többsége szerint a mikrobióta indukálja a gazdaszervezet IGFl-szintézisét, ezáltal befolyásolja a növekedést [66]. A dysbiosis egyre inkább az anyagcsere-rendellenességekhez kapcsolódik, a mikrobióta hatása a csontváz egészségére kevésbé érthető. Korábbi vizsgálatok szerint a mikrobióta károsítja a csontot a felszívódás növelésével. Yan és mtsai ezzel szemben azt találták, hogy a bélben élő mikrobióta elösegíti a csontképződést és a reszorpciót is, ami hosszú távon a csontváz nettó növekedését eredményezi. A mikrobióta indukálja az IGFl-et, ami elősegíti a csontnövekedést és a 'remodelinget'. A rövid láncú zsírsavak (SCFA-k), amelyek mikrobióták által fermentált rostokban keletkeznek, szintén IGFl-et indukálnak, ami olyan mechanizmusra utal, mellyel a mikrobióta befolyásolja a csont egészségét. A mikrobiótának vagy metabolitjainak manipulálása lehetőséget adhat a csontok egészségének és növekedésének optimalizálására. Az inzulinszerü növekedési faktor ismert csontváznövekedési hormon is, szérumszintje a mikrobiális kolonizáció hatására jelentősen megemelkedik, a máj és a zsírszövet IGFl-termelése megnövekszik. A konvencionális egerek antibiotikumkezelése ezzel szemben csökkenti a szérum-IGFl-et, és gátolja a csontképződést. Az antibiotikummal kezelt egereknek rövid láncú zsírsavak adása az IGFl-et és a csonttömeget helyreállítja az antibiotikummal nem kezelt egerekben megfigyelt szintekre [67].

\section{Az IGF és a cirkadián ritmus}

A molekuláris CLOCK (circadian locomotor output cycles kaput) mint domináns 'zeitgeber' ('időt adó', időzítő, szinkronizáló) biztosítja az energiaellátás állandóságát a szövetekben nappal és éjjel, a részt vevő sebességmeghatározó enzimek cirkadián oszcillációja útján. A cirkadián CLOCK-rendszer szabályozza a szervezet fon- tos neurohormonális tengelyének (hypothalamushypophysis, mellékvesék) aktivitását is [68]. Emlősökben a CLOCK és a BMALl (brain and muscle Arnt-like protein 1) bonyolult hálózatot alkot, mely további számos, ún. célgén múködését szabályozza. Idetartoznak a kriptokróm (Cry) és a period (Per) gének, melyeknek fontos szerepük van számos életfunkcióban [69].

A kalóriamegszorítás a BMALl aktivációjához és expressziójához vezet cirkadián CLOCK-függő vagy -független mechanizmusokon keresztül. A kalóriamegszorítás a SIRT1-et (szirtuinfehérje-család = silent information regulator 1 ) is aktiválja, amely szabályozhatja a CLOCKot és a BMALl-et. A SIRT1 aktivációja alacsony kalóriabevitel esetén kísérleti állatok megnyúlt élettartamának hátterében is kimutatható. Az extra aktivitás a hypothalamusban jelentkezik, amely az alapvető életfunkciókat - mint éhség, testhőmérséklet, stresszválasz és alvás-ébrenlét ciklusok - irányítja. A BMALl hozzájárul a keringő IGFl szintjeinek a kalóriamegszorítás mediálta szabályozásához. Az IGFl fontos tényezője az élettartam kalóriamegszorítás okozta meghosszabbodásának [70, 71]. Az IGFl-vérszintnek és az IGFl-jelátvitelnek cirkadián ritmusa van. A cirkadián szabályozás a kriptokrómokon (CRYs), a transzkripciós represszorokon és a cirkadián CLOCK-rendszer részein keresztül történik. Az IGFl-ritmus CRY-hiányos egerekben szétzilálódott, és az IGFl-szint 80\%-kal csökkent, ami az IGFl-jelátviteli út csökkenéséhez vezetett. A CRYs fontos szabályozó szerepet játszanak az IGFl termelésében és jelátvitelében. Legújabban német szerzők elsóként mutatták ki, hogy az IGFl közvetlenül befolyásolja a cirkadián BMALl-gén expresszióját a hypothalamicus sejtekben. A hypothalamussejteknek ez a szabályozása az IGFl újonnan felismert 'zeitgeber' szerepére utal [72].

\section{Következtetések}

1. Az inzulin-„,szupercsalád” koncepcióról szóló ismeretek kapcsán betekintést nyerhetünk az evolúció egy fontos pillanatába, amikor egy pluripotens, a növekedést, fejlődést, anyagcserét önmagában szabályozó prekurzor molekulából az egyes speciális folyamatokra 'szakosodott' molekulák alakultak ki. Az ősibb somatomedinek (későbbi nevükön IGF-ek) megtartották főként mitogén, növekedést, fejlődést szabályozó tulajdonságaikat, de a hypophysis GH-jával tengelyt képezve és az inzulinnal összhangban, jelenleg is részt vesznek az anyagcsere szabályozásában is.

2. Az IGF-eknek nagy szerepük van az embrionális és postnatalis fejlődésben, és később is - mint azt az adipocytafejlődés sejtvonala kapcsán láttuk - az éretlenebb sejtekben inkább az IGF-eknek, míg az érettekben az inzulinnak a szabályozó hatása érvényesül.

3. Az IGFl számos hatásmechanizmussal javítja az inzulinérzékenységet, T2DM-ben csökkenti az inzulinrezisztenciát. 
4. A GH-nak és az IGFl-nek fontos szerepe van a csontok és az izomzat kifejlődésében.

5. Az IGFl és -2 az agyi múködés fiziológiájában is nélkülözhetetlen.

6. Újonnan felfedezett endokrin szervünk, az intestinalis mikrobióta (is) indukálja az IGFl-et, ami elősegíti a csontnövekedést és a 'remodelinget'.

7. Az IGFl-vérszintnek és az IGFl-jelátvitelnek cirkadián ritmusa van. A cirkadián szabályozás a kriptokrómokon, transzkripciós represszorokon és a cirkadián CLOCK-rendszer részein keresztül történik.

8. Az IGF-ek hiánya vagy éppen túlzott jelenléte számos betegségben kimutatható, illetve ezekkel oki összefüggésbe hozható. Ennek taglalása, illetve terápiás konzekvenciái meghaladnák e cikk kereteit, ezért ezek egy következő közlemény tárgyát képezik.

Anyagi támogatás: A közlemény megírása anyagi támogatásban nem részesült.

Szerzői munkamegosztás: A szerzők egyenlő mértékben járultak hozzá a kézirat elkészítéséhez. A cikk végleges változatát mindkét szerző elolvasta és jóváhagyta.

Érdekeltségek: A szerzőknek nincsenek érdekeltségeik.

\section{Irodalom}

[1] Bayne ML, Applebaum J, Chicchi GG, et al. The roles of tyrosines 24,31 , and 60 in the high-affinity binding of insulin-like growth factor-I to the type 1 insulin-like growth factor receptor. J Biol Chem. 1990; 265: 15648-15652.

[2] Stretton AO. The first sequence: Fred Sanger and insulin. Genetics $2002 ; 162: 527-532$.

[3] Salmon WD Jr, Daughaday WH. A hormonally controlled serum factor which stimulates sulfate incorporation by cartilage in vitro. J Lab Clin Med. 1957; 49: 825-836.

[4] Salmon WD Jr, Burkhalter VJ. Stimulation of sulfate and thymidine incorporation into hypophysectomized rat cartilage by growth hormone and insulin-like growth factor-I in vitro: the somatomedin hypothesis revisited. J Lab Clin Med. 1997; 129: $430-438$.

[5] Rinderknecht E, Humbel RE. The amino acid sequence of human insulin-like growth factor I and its structural homology with proinsulin. J Biol Chem. 1978; 253: 2769-2776.

[6] Blumenthal S. From insulin and insulin-like activity to the insulin superfamily of growth-promoting peptides: a 20th-century odyssey. Perspect Biol Med. 2010; 53: 491-508.

[7] Aguirre GA, De Ita JR, de la Garza RG, et al. Insulin-like growth factor- 1 deficiency and metabolic syndrome. J Transl Med. 2016; 14: 3 .

[8] Brahmkhatri VP, Prasanna C, Atreya HS. Insulin-like growth factor system in cancer: novel targeted therapies. Biomed Res Int. 2015; 2015: 538019.

[9] Blundell TL, Humbel RE. Hormone families: pancreatic hormones and homologous growth factors. Nature 1980; 287: 781-787

[10] Clemmons DR. Metabolic actions of insulin-like growth factor-I in normal physiology and diabetes. Endocrinol Metab Clin North Am. 2012; 41: 425-443.
[11] Garten A, Schuster S, Kiess W. The insulin-like growth factors in adipogenesis and obesity. Endocrinol Metab Clin North Am. 2012; 41: 283-295.

[12] Denley A, Bonython ER, Booker GW, et al. Structural determinants for high-affinity binding of insulin-like growth factor II to insulin receptor (IR)-A, the exon 11 minus isoform of the IR. Mol Endocrinol. 2004; 18: 2502-2512.

[13] Costello M, Baxter RC, Scott CD. Regulation of soluble insulinlike growth factor II/mannose 6-phosphate receptor in human serum: Measurement by enzyme-linked immunosorbent assay. J Clin Endocrinol Metab. 1999; 84: 611-617.

[14] Clemmons DR, Dehoff MH, Busby WH, et al. Competition for binding to insulin-like growth factor (IGF) binding protein-2, 3 , 4 , and 5 by the IGFs and IGF analogs. Endocrinology 1992; 131: 890-895.

[15] Holly J, Perks C. The role of insulin-like growth factor binding proteins. Neuroendocrinology 2006; 83: 154-160.

[16] Clemmons DR. Role of insulin-like growth factor binding proteins in controlling IGF actions. Mol Cell Endocrinol. 1998; 140: 19-24.

[17] Rajpathak SN, Gunter MJ, Wylie-Rosett J, et al. The role of insulin-like growth factor-I and its binding proteins in glucose homeostasis and type 2 diabetes. Diabetes Metab Res Rev. 2009; 25: 3-12.

[18] Hoeflich A, Russo VC. Physiology and pathophysiology of IGFBP-1 and IGFBP-2 - consensus and dissent on metabolic control and malignant potential. Best Pract Res Clin Endocrinol Metab. 2015; 29: 685-700.

[19] Bar RS, Boes M, Clemmons DR, et al. Insulin differentially alters transcapillary movement of intravascular IGFBP-1, IGFBP-2 and endothelial cell IGF-binding proteins in the rat heart. Endocrinology 1990; 127: 497-499.

[20] Pollak M. The insulin and insulin-like growth factor receptor family in neoplasia: an update. Nat Rev Cancer 2012; 12: 159169.

[21] Laviola L, Natalicchio A, Giorgino F. The IGF-I signaling pathway. Curr Pharm Des. 2007; 13: 663-669.

[22] Orrù S, Nigro E, Mandola A, et al. Functional interplay between IGF-1 and adiponectin. Int J Mol Sci. 2017; 18: 2145.

[23] Leung KC, Johannsson G, Leong GM, et al. Estrogen regulation of growth hormone action. Endocr Rev. 2004; 25: 693-721.

[24] Merimee TJ, Zapf J, Froesch ER. Insulin-like growth factors in the fed and fasted states. J Clin Endocrinol Metab. 1982; 55: 999-1002.

[25] Clemmons DR. Involvement of insulin-like growth factor-I in the control of glucose homeostasis. Curr Opin Pharmacol. 2006; 6: 620-625.

[26] Fontana L, Villareal DT, Das SK, et al. Effects of 2-year calorie restriction on circulating levels of IGF-1, IGF-binding proteins and cortisol in nonobese men and women: a randomized clinical trial. Aging Cell 2016; 15: 22-27.

[27] Firth SM, Baxter RC. Cellular actions of the insulin-like growth factor binding proteins. Endocr Rev. 2002; 23: 824-854.

[28] Lewitt MS, Dent MS, Hall K. The insulin-like growth factor system in obesity, insulin resistance and type 2 diabetes mellitus. J Clin Med. 2014; 3: 1561-1574.

[29] Berg U, Bang P. Exercise and circulating insulin-like growth factor I. Horm Res. 2004; 62(Suppl 1): 50-58.

[30] Brahm H, Piehl-Aulin K, Saltin B, et al. Net fluxes over working thigh of hormones, growth factors and biomarkers of bone metabolism during short lasting dynamic exercise. Calcif Tissue Int. 1997; 60: 175-180.

[31] Carro E, Trejo JL, Busiguina S, et al. Circulating insulin-like growth factor I mediates the protective effects of physical exercise against brain insults of different etiology and anatomy. J Neurosci. 2001; 21: 5678-5684.

[32] Huffman DM, Farias Quipildor G, Mao K, et al. Central insulinlike growth factor-1 (IGF-1) restores whole-body insulin action 
in a model of age-related insulin resistance and IGF-1 decline. Aging Cell 2016; 15: 181-186.

[33] Bikle DD, Tahimic C, Chang W, et al. Role of IGF-I signaling in muscle bone interactions. Bone 2015; 80: 79-88.

[34] Pratipanawatr T, Pratipanawatr W, Rosen C, et al. Effect of IGFI on FFA and glucose metabolism in control and type 2 diabetic subjects. Am J Physiol Endocrinol Metab. 2002; 282: E1360E1368.

[35] Federici M, Giaccari A, Hribal ML, et al. Evidence for glucose/ hexosamine in vivo regulation of insulin/IGF-I hybrid receptor assembly. Diabetes 1999; 48: 2277-2285.

[36] Turkalj I, Keller U, Ninnis R, et al. Effect of increasing doses of recombinant human insulin-like growth factor-I on glucose, lipid, and leucine metabolism in man. J Clin Endocrinol Metab. 1992; 75: 1186-1191.

[37] Di Cola G, Cool MH, Accili D. Hypoglycemic effect of insulinlike growth factor-1 in mice lacking insulin receptors. J Clin Invest. 1997; 99: 2538-2544.

[38] del Rincon JP, Iida K, Gaylinn BD, et al. Growth hormone regulation of $\mathrm{p} 85 \alpha$ expression and phosphoinositide 3-kinase activity in adipose tissue: mechanism for growth hormone-mediated insulin resistance. Diabetes 2007; 56: 1638-1646.

[39] Yuen KC, Dunger DB. Therapeutic aspects of growth hormone and insulin-like growth factor-I treatment on visceral fat and insulin sensitivity in adults. Diabetes Obes Metab. 2007; 9: 11-22.

[40] Barbour LA, Mizanoor Rahman S, Gurevich I, et al. Increased $\mathrm{P} 85 \alpha$ is a potent negative regulator of skeletal muscle insulin signaling and induces in vivo insulin resistance associated with growth hormone excess. J Biol Chem. 2005; 280: 3748937494 .

[41] Wheatcroft SB, Kearney MT, Shah AM, et al. IGF-binding protein-2 protects against the development of obesity and insulin resistance. Diabetes 2007; 56: 285-294.

[42] Schedlich LJ, Le Page SL, Firth SM, et al. Nuclear import of insulin-like growth factor-binding protein- 3 and -5 is mediated by the importin $\beta$ subunit. J Biol Chem. 2000; 275: 23462-23470.

[43] Silha JV, Gui Y, Murphy LJ. Impaired glucose homeostasis in insulin-like growth factor-binding protein-3-transgenic mice. Am J Physiol Endocrinol Metab. 2002; 283: E937-E945.

[44] Scavo LM, Karas M, Murray M, et al. Insulin-like growth factorI stimulates both cell growth and lipogenesis during differentiation of human mesenchymal stem cells into adipocytes. J Clin Endocrinol Metab. 2004; 89: 3543-3553.

[45] DiGirolamo M, Edén S, Enberg G, et al. Specific binding of human growth hormone but not insulin-like growth factors by human adipocytes. FEBS Lett. 1986; 205: 15-19.

[46] Berryman DE, Glad CA, List EO, et al. The GH/IGF-1 axis in obesity: pathophysiology and therapeutic considerations. Nat Rev Endocrinol. 2013; 9: 346-356.

[47] Mauras N, O'Brien KO, Welch S, et al. Insulin-like growth factor $\mathrm{I}$ and growth hormone $(\mathrm{GH})$ treatment in $\mathrm{GH}$-deficient humans: differential effects on protein, glucose, lipid, and calcium metabolism. J Clin Endocrinol Metab. 2000; 85: 1686-1694.

[48] Fernández AM, Kim JK, Yakar S, et al. Functional inactivation of the IGF-I and insulin receptors in skeletal muscle causes type 2 diabetes. Genes Dev. 2001; 15: 1926-1934.

[49] Garten A, Schuster S, Kiess W. The insulin-like growth factors in adipogenesis and obesity. Endocrinol Metab Clin North Am. 2012; 41: 283-295.

[50] Laplante M, Sabatini DM. mTOR signaling in growth control and disease. Cell 2012; 149: 274-293.

[51] Cleveland-Donovan K, Maile LA, Tsiaras WG, et al. IGF-I activation of the AKT pathway is impaired in visceral but not subcutaneous preadipocytes from obese subjects. Endocrinology 2010; 151: 3752-3763.

[52] Gross DN, van den Heuvel AP, Birnbaum MJ. The role of FoxO in the regulation of metabolism. Oncogene 2008; 27: 23202336.
[53] Lewitt MS. The role of the growth hormone/insulin-like growth factor system in visceral adiposity. Biochem Insights 2017; 10: 1178626417703995.

[54] Garcia-Fernandez M, Sierra I, Puche JE, et al. Liver mitochondrial dysfunction is reverted by insulin-like growth factor II (IGF-II) in aging rats. J Transl Med. 2011; 9: 123.

[55] Castilla-Cortázar I, García-Fernández M, Delgado G, et al. Hepatoprotection and neuroprotection induced by low doses of IGF-II in aging rats. J Transl Med. 2011; 9: 103.

[56] Wolf E, Hoeflich A, Lahm H. What is the function of IGF-II in postnatal life? Answers from transgenic mouse models. Growth Horm IGF Res. 1998; 8: 185-193.

[57] Wang KC, Tosh DN, Zhang S et al. IGF-2R-G $\alpha$ q signaling and cardiac hypertrophy in the low-birth-weight lamb. Am J Physiol Regul Integr Comp Physiol. 2015; 308: R627-R635.

[58] Werner H, LeRoith D. Insulin and insulin-like growth factor receptors in the brain: physiological and pathological aspects. Eur Neuropsychopharmacol. 2014; 24: 1947-1953.

[59] Bondy CA, Werner H, Roberts CT Jr, et al. Cellular pattern of type-I insulin-like growth factor receptor gene expression during maturation of the rat brain: comparison with insulin-like growth factors I and II. Neuroscience 1992; 46: 909-923.

[60] Russo VC, Gluckman PD, Feldman EL, et al. The insulin-like growth factor system and its pleiotropic functions in brain. Endocr Rev. 2005; 26: 916-943.

[61] Devaskar SU, Giddings SJ, Rajakumar PA, et al. Insulin gene expression and insulin synthesis in mammalian neuronal cells. J Biol Chem. 1994; 269: 8445-8454.

[62] Åberg MA, Åberg ND, Hedbäcker H, et al. Peripheral infusion of IGF-I selectively induces neurogenesis in the adult rat hippocampus. J Neurosci. 2000; 20: 2896-2903.

[63] Trejo JL, Piriz J, Llorens-Martin MV, et al. Central actions of liver-derived insulin-like growth factor I underlying its pro-cognitive effects. Mol Psychiatry 2007; 12: 1118-1128.

[64] Alberini CM, Chen DY. Memory enhancement: consolidation, reconsolidation and insulin-like growth factor 2 . Trends Neurosci. 2012; 35: 274-283.

[65] D'Ercole AJ, Ye P, O'Kusky JR. Mutant mouse models of insulin-like growth factor actions in the central nervous system. Neuropeptides 2002; 36: 209-220.

[66] Yan J, Charles JF. Gut microbiota and IGF-1. Calcif Tissue Int. 2018; 102: 406-414.

[67] Yan J, Herzog JW, Tsang K, et al. Gut microbiota induce IGF-1 and promote bone formation and growth. Proc Natl Acad Sci U S A 2016; 113: E7554-E7563.

[68] Nader N, Chrousos GP, Kino T. Circadian rhythm transcription factor CLOCK regulates the transcriptional activity of the glucocorticoid receptor by acetylating its hinge region lysine cluster: potential physiological implications. FASEB J. 2009; 23: 15721583.

[69] Reick M, Garcia JA, Dudley C, et al. NPAS2: an analog of clock operative in the mammalian forebrain. Science 2001; 293: 506509.

[70] Maury E, Ramsey KM, Bass J. Circadian rhythms and metabolic syndrome: from experimental genetics to human disease. Circ Res. 2010: 106: 447-462.

[71] Chaudhari A, Gupta R, Patel S, et al. Cryptochromes regulate IGF-1 production and signaling through control of JAK2-dependent STAT5B phosphorylation. Mol Biol Cell 2017; 28: 834-842.

[72] Breit A, Miek L, Schredelseker J, et al. Insulin-like growth factorI acts as a zeitgeber on hypothalamic circadian clock gene expression via glycogen synthase kinase- $3 \beta$ signaling. J Biol Chem. 2018; 293: 17278-17290.

(Halmos Tamás dr., Budapest, Kikelet u. 43/a, 1125 e-mail: fishwash@t-online.hu) 